\title{
Correction to: A Subtractive FACS Method for Isolation of Planarian Stem Cells and Neural Cells
}

\author{
Tetsutaro Hayashi and Kiyokazu Agata
}

\section{Correction to:}

Chapter 19 in: Jochen C. Rink (ed.), Planarian Regeneration:

Methods and Protocols, Methods in Molecular Biology, vol. 1774, https://doi.org/10.1007/978-1-4939-7802-1_19

The original version of this chapter was inadvertently published without the below mentioned code listings in Chapter 19.

\subsection{Cell Staining for Stem Cell Isolation}

1. Add $18 \mu \mathrm{L}$ of Hoechst 33342 stock solution and $0.5 \mu \mathrm{L}$ of calcein AM stock solution to the filtered samples (Subheading 3.1, step 8) ( see Note 10).

2. Invert the sample tubes about three times and incubate for $120 \mathrm{~min}$ at $20^{\circ} \mathrm{C}$ ( see Note 11 ).

3. Pellet by centrifuging at $1500 \times g$ for $5 \mathrm{~min}$ and remove the supernatants. Resuspend cell pellets with $2 \mathrm{~mL}$ (two sample volumes) of $5 / 8$ Holtfreter's.

4. Add PI stock solution at $1 \mu \mathrm{L} / \mathrm{mL}$ to the cell suspensions and incubate at least $5 \mathrm{~min}$ on ice.

5. Proceed to FACS analysis or microscopy.

The code listings have been updated in the same chapter.

The updated online version of this chapter can be found at

https://doi.org/10.1007/978-1-4939-7802-1_19 